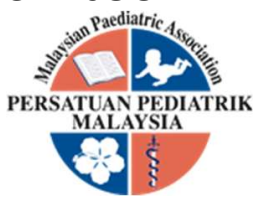

\title{
SEXUAL HEALTH KNOWLEDGE AND ATTITUDE AMONG THE SEXUALLY ABUSED ADOLESCENTS: A SINGLE CENTRE STUDY
}

\author{
Nor Rosidah Ibrahim ', Susilowati Heru Subono ${ }^{1}$, Fahisham Taib ${ }^{1,2}$, Norsarwany Mohamad'
}

\begin{abstract}
Introduction: Sexual education is an important step to prevent unwanted pregnancy, abortions and sexual transmitted diseases (STDs) in adolescent. Assessment of the sexual health knowledge and the attitude towards premarital sexual activity are essential to fill in this gap of knowledge. Objective: The objective of this study was to examine the knowledge on the sexual health and attitude towards premarital sexual activity among the sexually abused adolescent. Methods: A cross-sectional study was conducted among 88 female teenagers who were admitted to Hospital Universiti Sains Malaysia for sexual abuse. Using a self-administered validated Malay questionnaire, participants were guided to answer the question on knowledge and attitude. The attitude was categorized to a permissive and nonpermissive attitude. Simple and multiple binary logistic regression were used to analyze the associated factors with the attitude. Result: The lowest percentage of correct responses included: penile discharge during ejaculation contains sperm (5.7\%), pregnancy may not occur if having sexual intercourse once only (26.1\%), having vaginal washing after sexual intercourse prevents pregnancies (19.3\%). Forty-one $(48.0 \%)$ of participants had a permissive attitude whereas forty-seven (53.4\%) had a non-permissive attitude toward premarital sexual activity. Simple and multiple logistic regressions did not reveal any significant associated factors. Conclusion: The sexual health knowledge among sexually abused children was inadequate and they were at risk of permissive attitude toward premarital sexual activity. We could not identify any factors related to the permissive attitude in our study.
\end{abstract}

Keywords: Sexual health, adolescent, sexual abuse, knowledge

DOI: $10.51407 /$ mjpch.v27i2.141

\section{Introduction}

Sexual abuse among children has become a significant public health issue in both developed and developing countries. There were 3257 cases of child abuse reported in 2010 in Malaysia and $29 \%$ of them were sexual abuse [1]. More than half of the cases $(51.7 \%)$ involved teenagers who were living in urban setting [2]. The proportion of teenagers who had sexual intercourse in Malaysia (5.4\%) was still lower compared to other countries (Thailand 15\%, Brazil 33\%, Great Britain 60\% and USA 50\%) [2]. The current figure did not reflect the actual number since majority of the cases were undetected. The consequences of sexual abuse may directly affect the individual child,

\author{
Received: 24 December 2020; Accepted revised \\ manuscript: 03 October 2021 \\ Published online: 26 October 2021
}

family dynamic, social well-being and the religion-cultural context [3].

Many Malaysian teenagers are sexually active and may engage in high-risk sexual activities [4]. Changes in sexual hormones levels and cultural evolution fantasizing pleasure of romance and sex has given rise to premarital sexual activity, teenage pregnancy and sexually transmitted

'Department of Paediatrics, School of Medical Sciences, 16150, Universiti Sains Malaysia, Kubang Kerian, Kelantan, Malaysia ${ }^{2}$ SCAN team, Hospital Universiti Sains Malaysia, 16150 Kubang Kerian, Kelantan, Malaysia

Corresponding Author:

Norsarwany Mohamad, Department of Paediatrics, School of Medical Sciences, Health Campus, Universiti Sains Malaysia,

16150 Kota Bharu, Kelantan, Malaysia

Tel.: +6097673000 Email: sarwany@usm.my 
diseases [5,6,7]. Sexually abused children are managed under the Hospital Suspected Child Abuse and Neglect (SCAN) team. Most of victims in these cases were female and approximately one-fifth of the sexual offence was performed by a known person [8].

The previous assessment of sexual health knowledge among teenager was developed for sex education. Lack of sexual health knowledge was one of the contributing factors identified in many of the sexual encounters in teenagers $[9,10,11]$. The relationship between knowledge and sexual behavior is complex. Knowledge has various effect on behavior, but it is an important component for the informed sexual behavior [12]. Social stigma, cultural discrepancy and religiosity might influence their way of thinking.

Girls are vulnerable group for sexual abuse compared to boys $[13,14]$. Failure to say 'no' for any sexual activities have contributed to the silent acceptance and violence in children [15]. Premarital sexual activity is strongly discouraged in many cultures, because virginity is perceived as valuable and precious [16]. Religion has been considered protective and tend to delay initial sexual debut and minimizing sexual partners [17] and others found that strong religious beliefs have not shown any effect [18].

The aim of this study was to assess the knowledge, attitude and explore the factors associated with the premarital sexual activity among the teenagers admitted under SCAN team at Hospital Universiti Sains Malaysia (USM).

\section{Methodology}

\section{Study design}

A cross-sectional, self-administered questionnaire was distributed to the teenagers who were admitted under the SCAN team for child sexual abuse.

\section{Study setting and participants}

The study was conducted from May 2011 until June 2012 at Hospital USM, one of the referral centres for child abuse cases, covering the districts such as Bachok, Pasir Puteh and north part of Terengganu. The participants were identified from admission records from the One Stop Crisis Centre (OSCC) data. Patients were recruited from the wards, emergency department and while attending outpatient clinic follow up.

\section{Instrument}

The questionnaire consists of 3 parts - sociodemographic information, sexual health knowledge and sexual health attitudes. The Malay version questionnaire has undergone validation process to assess the sexual health knowledge and attitudes among the secondary school students in Kelantan, with the Cronbach Alpha more than $0.7 \quad[8,18]$. The demographic information covers respondents' age, gender, race, religion, education level, family background and school activities. The knowledge section on sexual health has 23 items and attitudes towards the practice of premarital sexual activity section has 16 items.

The questionnaire on sexual health knowledge offers three options which are True/Correct, False/Wrong and Don't know. For a correct response, a score of 2 was given. For an incorrect response, a score of 0 was given and a score of 1 for 'Don't know' answer. Maximum score that could be obtained was 46 . The higher the total score reflects the better sexual health knowledge.

The attitude component was assessed using Likert scale ("Strongly Agree," "Agree," "Not Sure," "Not Agree," "Strongly not agree,") and the score were given based on acceptable and unacceptable statement, ranging from "4" for acceptable statement to " 0 " for unacceptable statement. The mean score of 48.0 were used to categorize into permissive and non-permissive attitude towards premarital sexual activity. The score below the mean reflects of having permissive attitude.

\section{Sample and Data collection}

Teenagers admitted under the SCAN team for sexual abuse were approached. They can also be those who were admitted previously but has been discharged and attended outpatient followup clinic during the study period. Teenagers aged between 13 to 17 years old and agreed to participate were included and those with mental retardation were excluded. Once the subject was approached, the questionnaire was explained and guided by the researcher. Only one researcher who assisted the participants to fill up 
the questionnaire to reduce the risk of bias. Informed consent was obtained from their parent and assent from the patients prior to answering of the questionnaire. Participants were allowed to opt out from the study if they do not wish to participate in the study.

\section{Statistical Analysis}

All data were entered using SPSS version 20.0 for Macintosh (SPSS Inc). Descriptive statistics were used to describe socio-demographic information. Categorical data was expressed in number and percentage. Numerical data was expressed in mean and standard deviation (SD). Non-normally distributed data was described as median and interquartile range (IQR). Knowledge and attitude were expressed as frequency and percentages. Multiple Logistic Regression were used to analyse the factors in the demographic profiles associated with having permissive attitude towards premarital sexual activity.

\section{Ethical approval}

The study's ethical was obtained from the Research and Ethics Committee, School of
Medical Sciences, Universiti Sains Malaysia (USM/PPSP/2010/JKP-41[41.3(2)].

\section{Results}

\section{Socio-demographic Data}

A total of 88 participants were included in the study. All were female with $98.9 \%$ identified as Malay Muslim. The mean age of the participants was 15-year-old (SD of 1.24). Sixty seven percent have a close relationship with their parents.

Most parents of the participants had formal education up to secondary school level $(80.7 \%$ in father and $75.0 \%$ in mother). The parents were employed with $53.4 \%$ working mothers and $89.8 \%$ working fathers. Forty two percent of the families from the monthly household income of RM 1000 or less; and a significant $28.4 \%$ of them has gross monthly income of RM500 or less (Table 1).

Table 1. Socio-demographic characteristics of the study subjects $(n=88)$

\begin{tabular}{|c|c|}
\hline & n (\%) \\
\hline \multicolumn{2}{|l|}{ Race } \\
\hline Malay & $87(98.70)$ \\
\hline Non-Malay & $1(1.23)$ \\
\hline Age (years) & $15(1.24)^{\mathrm{a}}$ \\
\hline 13 & $9(10.20)$ \\
\hline 14 & $25(28.40)$ \\
\hline 15 & $21(23.90)$ \\
\hline 16 & $20(22.70)$ \\
\hline 17 & $13(14.80)$ \\
\hline \multicolumn{2}{|l|}{ Education level } \\
\hline Never have formal education & $2(2.30)$ \\
\hline Primary school & $2(2.30)$ \\
\hline Secondary school & $81(92.00)$ \\
\hline College/university & $3(3.40)$ \\
\hline \multicolumn{2}{|l|}{ School activity } \\
\hline Active & $37(42.00)$ \\
\hline Not active & $51(58.00)$ \\
\hline \multicolumn{2}{|l|}{ Relationship with parents } \\
\hline Close & $59(67.00)$ \\
\hline Not close & $29(33.00)$ \\
\hline \multicolumn{2}{|l|}{ Parent's relationship } \\
\hline Staying together & $66(75.00)$ \\
\hline Separated & $22(25.00)$ \\
\hline \multicolumn{2}{|l|}{ Mother's education level } \\
\hline Never have formal education & $2(2.30)$ \\
\hline Primary school & $16(18.20)$ \\
\hline
\end{tabular}




\begin{tabular}{ll}
\hline Secondary school & $66(75.00)$ \\
College/university & $4(4.50)$ \\
Father's education level & \\
Never have formal education & $2(2.30)$ \\
Primary school & $12(13.60)$ \\
Secondary school & $71(80.70)$ \\
College/university & $3(3.40)$ \\
Parent's employment status & \\
Mother & $47(53.40)$ \\
Employed & $41(46.60)$ \\
Unemployed & \\
Father & $79(89.80)$ \\
Employed & $9(10.20)$ \\
Unemployed & \\
Parental Income & $25(28.40)$ \\
Less than RM500 & $37(42.00)$ \\
RM500-RM1000 & $20(22.70)$ \\
RM1001-RM2000 & $6(6.80)$ \\
More than RM 2000 & \\
Family member & $27(30.70)$ \\
1-5 & $61(6.80)$ \\
More than 5 & \\
\hline
\end{tabular}

a Mean (standard deviation).

\section{Knowledge on sexual and reproductive health among the sexually abused children}

The lowest percentage of correct responses came from the following items: penile discharge during ejaculation contains sperm (5.7\%), pregnancy may not occur if having sexual intercourse once only (26.1\%), vaginal washing after sexual intercourse prevents pregnancies (19.3\%) and sexual intercourse is a cause of STDs (47.5\%).
Many participants knew that they have to sleep separately from different gender of the family member $(87.5 \%)$, there is relationship between abandoned babies and premarital pregnancies (71.6\%) and sexual abstinence is the best method to prevent pregnancy (68.2\%) (Table 2). Correct responses on knowledge was considered when the responses were above $60 \%$ of the total response.

Table 2. Correct responses to questions assessing knowledge on sexual health among sexually abused children

\begin{tabular}{|c|c|c|}
\hline Items & $\mathbf{n}$ & $\%$ \\
\hline The ovary produces egg or ovum. & 42 & 47.7 \\
\hline The vagina is the organ for delivery of babies. & 42 & 47.7 \\
\hline The vagina is the organ for menstruation. & 44 & 50.0 \\
\hline The uterus is the organ where a fetus stays. & 54 & 51.0 \\
\hline $\begin{array}{l}\text { The genitalia maybe touched freely by family } \\
\text { members. }\end{array}$ & 69 & 78.0 \\
\hline $\begin{array}{l}\text { Penile discharge during ejaculation contains sperm. } \\
\text { You have to sleep separately from different gender of }\end{array}$ & 5 & 5.7 \\
\hline $\begin{array}{l}\text { the family member. } \\
\text { Female who reach menarche can become pregnant if }\end{array}$ & 77 & 87.5 \\
\hline $\begin{array}{l}\text { they have sex. } \\
\text { Pregnancy may occur if there is penetration of the }\end{array}$ & 46 & 52.3 \\
\hline $\begin{array}{l}\text { vagina by the penis. } \\
\text { Pregnancy occurs when there is fertilization by the }\end{array}$ & 52 & 59.1 \\
\hline $\begin{array}{l}\text { ovum with sperm. } \\
\text { Pregnancy may not occur if having sexual intercourse }\end{array}$ & 45 & 51.1 \\
\hline
\end{tabular}




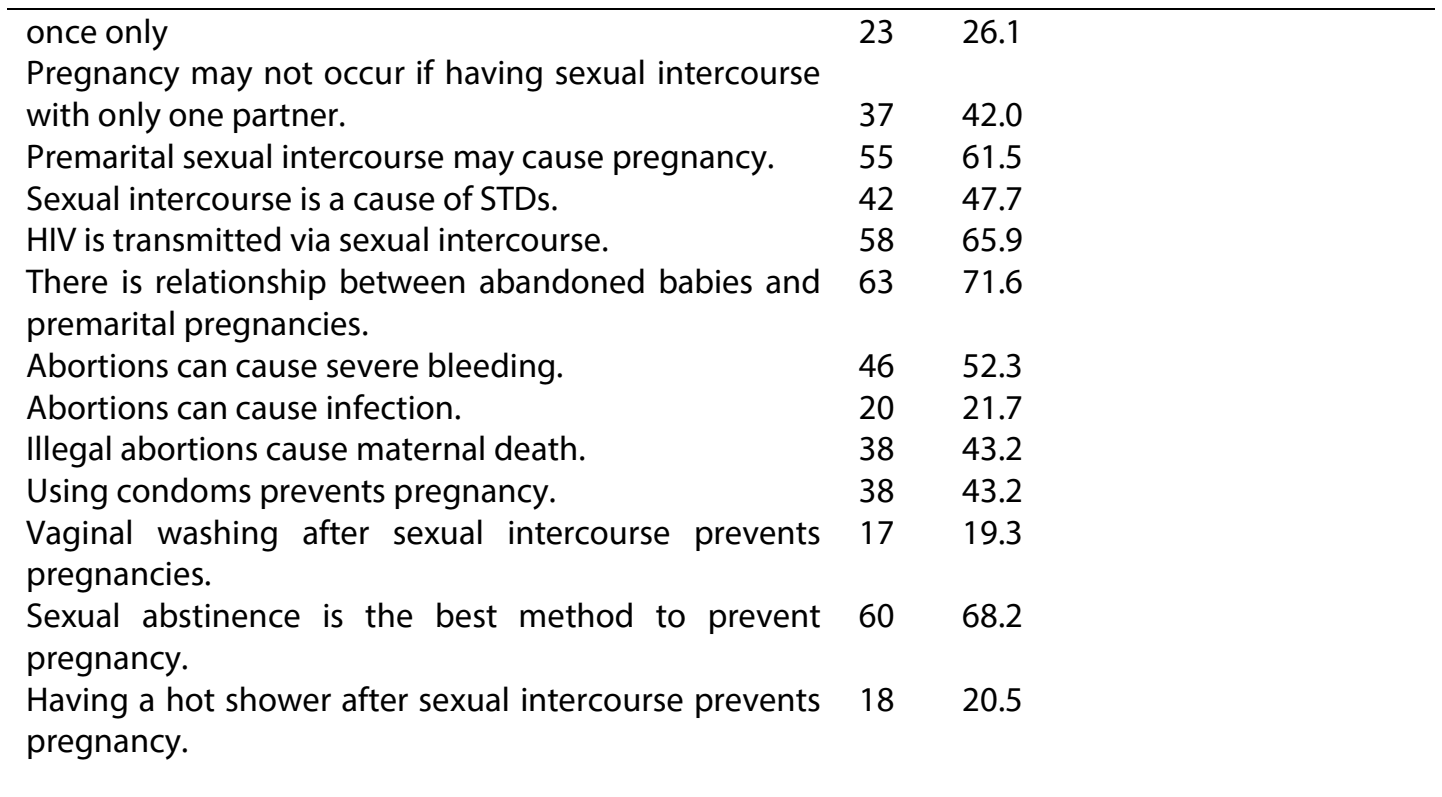

\section{Level of attitude towards premarital sexual activity among sexually abused children}

Based on the mean score, those with mean score less than 48 were categorized to have permissive attitude. The permissive and non-permissive attitude was based on total median score of level of attitude items. Permissive attitude was defined as the attitudes toward accepting the practice of premarital sexual activity [19]. Those with mean score of 48 and above were categorized into nonpermissive attitude. There were $41(48.0 \%)$ participants who had permissive attitude and the remaining 47 (53.4\%) had non-permissive attitude toward premarital sexual activity (Table 3).

Table 3. Responses to questions on attitude towards premarital sexual activity

\begin{tabular}{|c|c|c|c|c|c|}
\hline Attitude & $\begin{array}{l}\text { Strongly } \\
\text { agree } \\
\text { n (\%) }\end{array}$ & $\begin{array}{l}\text { Agree } \\
\text { n (\%) }\end{array}$ & $\begin{array}{l}\text { Not sure } \\
\text { n (\%) }\end{array}$ & $\begin{array}{l}\text { Disagree } \\
\text { n (\%) }\end{array}$ & $\begin{array}{l}\text { Strongly } \\
\text { disagree } \\
\mathrm{n}(\%)\end{array}$ \\
\hline $\begin{array}{l}\text { You are interested to have sexual } \\
\text { intercourse before marriage }\end{array}$ & $0(0.00)$ & $4(4.50)$ & $14(15.90)$ & $35(39.80)$ & $35(39.80)$ \\
\hline $\begin{array}{l}\text { Having sexual intercourse before } \\
\text { marriage is not wrong }\end{array}$ & $1(1.10)$ & $4(4.50)$ & $7(8.00)$ & $31(35.20)$ & $45(57.10)$ \\
\hline $\begin{array}{l}\text { Adolescent who have never involved } \\
\text { in sexual intercourse before marriage } \\
\text { are dull or not attractive }\end{array}$ & $1(1.10)$ & $5(5.70)$ & $16(18.20)$ & $28(31.80)$ & $38(43.20)$ \\
\hline $\begin{array}{l}\text { Adolescent who have never involved } \\
\text { in sexual intercourse before marriage } \\
\text { are old-fashioned }\end{array}$ & $0(0.00)$ & $3(3.40)$ & $12(13.60)$ & $37(420)$ & $36(40.90)$ \\
\hline $\begin{array}{l}\text { Having sexual intercourse with same } \\
\text { gender (homosexuals) is not wrong }\end{array}$ & $1(1.10)$ & $2(2.30)$ & $9(10.20)$ & $31(35.20)$ & $35.2(51.10)$ \\
\hline People who have sexual intercourse & $16(18.20)$ & $20(22.70)$ & $9(10.20)$ & $21(23.90)$ & $22(25.00)$ \\
\hline
\end{tabular}




\begin{tabular}{|c|c|c|c|c|c|}
\hline $\begin{array}{l}\text { Holding hands with your boyfriend } \\
\text { while experiencing sexual excitement } \\
\text { in secluded or public places is not } \\
\text { wrong }\end{array}$ & $1(1.10)$ & $3(3.40)$ & $6(6.80)$ & $38(43.20)$ & $40(45.50)$ \\
\hline $\begin{array}{l}\text { Touching another person's body } \\
\text { parts with sexual excitement is not } \\
\text { wrong }\end{array}$ & $0(0.00)$ & $5(5.70)$ & $7(8.00)$ & $36(40.90)$ & $40(40.50)$ \\
\hline $\begin{array}{l}\text { It is not wrong if you only kiss your } \\
\text { boyfriend/girlfriend }\end{array}$ & $0(0.00)$ & $3(3.40)$ & $11(12.50)$ & 39 (44.50) & 35 (39.80) \\
\hline $\begin{array}{l}\text { It is not wrong if you just hug your } \\
\text { boyfriend/girlfriend }\end{array}$ & $1(1.10)$ & $5(5.70)$ & $10(11.40)$ & $40(45.50)$ & $32(36.40)$ \\
\hline $\begin{array}{l}\text { Kissing/necking without having } \\
\text { sexual intercourse is not wrong }\end{array}$ & $1(1.10)$ & $3(3.40)$ & $14(15.90)$ & $41(46.60)$ & $29(33.0)$ \\
\hline $\begin{array}{l}\text { You feel proud because your } \\
\text { boyfriend is protecting your honor }\end{array}$ & $14(15.90)$ & $21(23.90)$ & $18(20.50)$ & $16(18.20)$ & 19 (21.60) \\
\hline $\begin{array}{l}\text { You feel proud because your } \\
\text { boyfriend is respect to you }\end{array}$ & $6(6.80)$ & $15(17.00)$ & $23(26.10)$ & $20(22.70)$ & $24(27.30)$ \\
\hline $\begin{array}{l}\text { You do not want to be pregnant } \\
\text { before marriage }\end{array}$ & $6(6.80)$ & $7(8.00)$ & $7(8.00)$ & $30(34.10)$ & $38(43.20)$ \\
\hline $\begin{array}{l}\text { Abandonment } \quad \text { babies } \\
\text { cruel/inhumane }\end{array}$ & $10(11.40)$ & $8(9.10)$ & $4(4.50)$ & $22(25.00)$ & $44(50)$ \\
\hline $\begin{array}{l}\text { Sexual intercourse is only permissible } \\
\text { after marriage }\end{array}$ & $10(11.40)$ & $5(5.70)$ & $8(9.10)$ & $20(22.70)$ & $45(51.10)$ \\
\hline
\end{tabular}


Using simple logistic regression, demographic factors in the dataset were explored. None of the factors explored were significant from the multiple logistic regression analysis (Table 4 and Table 5).

Table 4. Factors Associated with Attitudes towards Premarital Sexual Activities

\begin{tabular}{|c|c|c|c|c|}
\hline Variables & $\begin{array}{l}\text { Non-permissive } \\
\text { Attitude, n (\%) }\end{array}$ & $\begin{array}{l}\text { Permissive } \\
\text { Attitude, n (\%) }\end{array}$ & $\begin{array}{l}\text { Crude OR } \\
(95 \% \mathrm{CI})\end{array}$ & $\begin{array}{l}P \text { value of Wald } \\
\text { Statistics }\end{array}$ \\
\hline \multicolumn{5}{|l|}{ Age (years) } \\
\hline $15-17$ & $26(48.10)$ & $28(51.90)$ & & \\
\hline $13-14$ & $21(61.80)$ & $13(38.20)$ & $0.57(0.24,1.37)$ & 0.214 \\
\hline \multicolumn{5}{|l|}{ Knowledge } \\
\hline Score $\geq 33$ & $22(22.50)^{a}$ & $26(22.40)^{a}$ & & \\
\hline Score $<33$ & $25(21.40)^{a}$ & $15(18.60)^{a}$ & $1.97(0.83,4.63)$ & 0.120 \\
\hline \multicolumn{5}{|l|}{$\begin{array}{l}\text { Relationship } \\
\text { with parents }\end{array}$} \\
\hline Good & $31(52.50)$ & $28(47.50)$ & & \\
\hline Poor & $16(55.20)$ & $13(44.80)$ & $1.11(0.45,2.71)$ & 0.816 \\
\hline \multicolumn{5}{|l|}{$\begin{array}{l}\text { Relationship } \\
\text { with sibling }\end{array}$} \\
\hline Good & $33(55.90)$ & $26(44.10)$ & & \\
\hline Poor & $14(48.30)$ & $15(51.70)$ & $0.73(0.30,1.79)$ & 0.499 \\
\hline \multicolumn{5}{|l|}{ Mother } \\
\hline Lower & $11(61.10)$ & $7(38.90)$ & $1.48(0.51,4.27)$ & 0.464 \\
\hline $\begin{array}{l}\text { Father } \\
\text { educational level } \\
\text { Higher } \\
\text { Lower }\end{array}$ & $\begin{array}{l}40(54.10) \\
7(50.00)\end{array}$ & $\begin{array}{l}34(45.90) \\
7(50.00)\end{array}$ & $0.85(0.27,2.66)$ & 0.781 \\
\hline $\begin{array}{l}\text { Parent's work } \\
\text { Mother } \\
\text { Unemployed } \\
\text { Employed }\end{array}$ & $\begin{array}{l}25(61.00) \\
22(46.80)\end{array}$ & $\begin{array}{l}16(39.00) \\
25(53.20)\end{array}$ & $0.56(0.24,1.31)$ & 0.185 \\
\hline $\begin{array}{l}\text { Father } \\
\text { Unemployed } \\
\text { Employed }\end{array}$ & $\begin{array}{l}3(33.30) \\
44(55.70)\end{array}$ & $\begin{array}{l}6(66.70) \\
35(44.30)\end{array}$ & $0.39(0.09,1.70)$ & 0.214 \\
\hline $\begin{array}{l}\text { Total income } \\
\text { Higher } \\
\text { Lower }\end{array}$ & $\begin{array}{l}15(57.70) \\
32(51.60)\end{array}$ & $\begin{array}{l}11(42.30) \\
30(48.40)\end{array}$ & $0.78(0.31,1.97)$ & 0.602 \\
\hline $\begin{array}{l}\text { Parents' } \\
\text { relationships } \\
\text { Stay together } \\
\text { Separated }\end{array}$ & $\begin{array}{r}39(59.10) \\
8(36.40)\end{array}$ & $\begin{array}{l}27(40.90) \\
14(63.30)\end{array}$ & $0.79(0.14-1.04)$ & 0.066 \\
\hline $\begin{array}{l}\text { School activity } \\
\text { Involved } \\
\text { Not involved }\end{array}$ & $\begin{array}{l}21(56.80) \\
26(51.00)\end{array}$ & $\begin{array}{l}16(43.20) \\
25(49.00)\end{array}$ & $0.79(0.33,1.85)$ & 0.592 \\
\hline
\end{tabular}


Table 5. Factors associated with Attitude Towards Premarital Sexual Activity Analyzed by Multiple Logistic Regression

\begin{tabular}{|c|c|c|c|c|}
\hline Variables & $\begin{array}{l}\text { Non- permissive } \\
\text { Attitude, } n(\%)\end{array}$ & $\begin{array}{c}\text { Permissive } \\
\text { attitude, } n(\%)\end{array}$ & $\begin{array}{c}\text { Adjusted OR } \\
(95 \% \mathrm{Cl})\end{array}$ & $P$ value \\
\hline \multicolumn{5}{|l|}{ Age (years) } \\
\hline $15-17$ & $26(48.10)$ & $28(51.90)$ & & \\
\hline $13-14$ & $21(61.80)$ & $13(38.20)$ & $0.77(0.30,1.98)$ & 0.595 \\
\hline \multicolumn{5}{|l|}{ Knowledge } \\
\hline Score $\geq 33$ & $22(22.50)$ & $26(22.40)$ & & \\
\hline Score $<33$ & $25(21.40)$ & 15 (18.60) & $0.52(0.21,1.28)$ & 0.155 \\
\hline \multicolumn{5}{|l|}{ Parent's work } \\
\hline \multicolumn{5}{|l|}{ Mother } \\
\hline Unemployed & $25(61.00)$ & $16(39.00)$ & & \\
\hline Employed & $22(46.80)$ & $25(53.20)$ & $1.63(0.66,4.02)$ & 0.287 \\
\hline \multicolumn{5}{|l|}{ Father } \\
\hline Unemployed & $3(33.30)$ & $6(66.70)$ & & \\
\hline Employed & $44(55.70)$ & 35 (44.30) & $1.56(0.33,7.47)$ & 0.575 \\
\hline \multicolumn{5}{|l|}{$\begin{array}{l}\text { Parent's } \\
\text { relationship }\end{array}$} \\
\hline Stay together & $39(59.10)$ & $27(40.90)$ & & \\
\hline Separated & $8(36.40)$ & $14(63.30)$ & $0.72(0.44,1.18)$ & 0.192 \\
\hline
\end{tabular}

Backward LR Multiple Logistic regression was applied

Multicollinearity and interaction term were checked and not found

Hosmer-Lemeshow test $(p=0.408$ ), classification table (overall correctly classified percentage $=65.9$ ) and area under the ROC curve (70.5\%) were applied to check the model fitness.

\section{Discussion}

Kelantan is a state in the North East of peninsular Malaysia, predominantly inhabited by Malay population with diverse cultural background. Hospital USM was a 786 bedded tertiary hospital receiving referral of many types of child abuse cases. The cases were managed by SCAN team, who worked as part of the multi-disciplinary team to resolve social emergency in child maltreatment. A total of 88 participants were included with the mean age of 15-year-old and almost all of them were in secondary schools. Majority of the participants came from a low social economic background with monthly income between RM 500 to RM 1000. These findings were consistent with other studies [19]. Another significant finding were parental education level were up to secondary school in more than $80 \%$ for father and $75 \%$ for mother respectively. Previous study [19] did not reflect similar parental demographic background.
Permissive attitude towards premarital sexual activity in these adolescents was prominent in the lower socioeconomic group. These parents work to support the family survival, hence affecting home monitoring and supervision of their children's activities. Parental psychosocial dynamic such as single parent also contributed to the permissive attitude towards premarital sexual activity $[20,21]$. It is understood that parentalchildren relationship shapes the attitude of adolescent, with higher proportion of nonpermissive attitude to have a closer relationship with the parents [19].

Poor sexual and reproductive health knowledge is related to increasing sexual activity. This was reflected from reproductive system items, that less than fifty percent of the participants responded correctly. In our study, we found lack of sexual health knowledge in the lower socioeconomic group leading to school absenteeism, poor school performance and sexual health 
illiteracy despite the introduction of sex education in the secondary education. About $70 \%$ of adolescents gave correct responses to the question of "they should sleep separately from different sex of family member" and "genitalia maybe touched freely by family members". This findings indicate a positive influence of the cultural and religious practice on sexual behaviour among adolescent[19].

More than $50 \%$ of participant were aware that a girl could be pregnant once they achieved menarche and involved in premarital sexual intercourse. Only small percentage (23\%)of them knew that by having sexual intercourse once only or with only one partner (37\%) may lead to pregnancy. Many of the subjects in our study did not use protection in their first sexual intercourse as per previous study [22]. Even many sexually active women did not use contraception during the first-time sexual encounter.

Knowledge on complications of premarital sexual activity was also inadequate. They had better knowledge on STDs (47.7\%) and HIV (65.9\%) compared with knowledge on abortion. Less than forty percent of them gave correct responses about complication of abortion. Sixty-eight percent of the participants understood that sexual abstinence is the best method to prevent pregnancy with less than twenty percent of them believed that vaginal washing and hot shower after sexual intercourse prevent pregnancy. Adolescents in our cohort may have awareness on the subject such as prevention of pregnancy, however, the deep understanding or knowledge seemed to be inadequate. This probably translated to their practice especially in the case of sexual abstinence.

Our study also revealed that participants have received reproductive health information from multiple resources. Teachers were the most common source of information (36.2\%) followed by friends (23.5\%) and parents (17.6\%). However, a local study found that friends (64.3\%) and mass media $(60.2 \%)$ were the most common source of information as compared to teacher (17.2\%) and parents (6.5\%) [8]. In US, the internet has been the medium for teenagers to learn sex education, since almost all adolescent around the world are using the internet as the source of information [23].

\section{Factors associated with attitude towards premarital sexual activity}

The percentage of adolescents' attitude towards premarital sexual activity was highly recognized in the older age group (15-17 years) compared with younger age group. In contrast, younger students were more likely to have permissive attitude towards premarital sexual activities compared with older age group [18]. Other study reported that younger students had more nonpermissive attitudes compared with older students [24].

A US survey found that there were $5.7 \%$ of teen reported sexual intercourse before the age of 14 years old [25]. The finding illustrated that younger adolescents may be less likely to have engaged in premarital sexual activity since their poor readiness for activity outside the home. The older teenagers are exposed to peer group pressure and being away from parental supervision which have drawn them to their sexual activity.

The trend of knowledge on sexual health was found to be lower in adolescent with permissive attitude compared with non-permissive attitude. Having a good knowledge on sexual health should protect teenagers from practicing permissive attitude towards premarital sexual activity [19]. Other previous study also found that poor knowledge was a risk factor for premarital sexual activity [26,27]. Higher proportion of participants with non-permissive attitude (53.3\%) reported to have a close relationship with their parents. The finding contradicted with other previous study, which found that good parentsadolescent relationship and interaction did not significantly influence on their adolescent sexuality [24]. Parental talk on sexuality to their teenagers at earlier age before they engaged in sexual activity were related to better sexual decision making [24]. Parents found it challenging to talk to teenagers about sex within the Malaysian culture. Parents would feel awkward and uncomfortable when the topics were being discussed with their children [28]. They would rather avoid talking on sexual matter with their children, to avoid the idea of premarital sexual activity [29].

The limitations of this study were small sample size of the participants which could influence the ability to delineate factors that might have influenced the statistical outcome. The study was 
also conducted in a single centre and the result might not be generalizable to the surrounding ethnics in Malaysia.

\section{Conclusion}

The sexual health knowledge among sexually abused children was inadequate and they were at risk of permissive attitude toward premarital sexual activity. We could not identify any factors related to the permissive attitude in our study Conclusion.

\section{Acknowledgement}

The study has received a Short-Term Grant from Universiti Sains Malaysia with the amount of RM 26,033.20 (PPK/ST-514).

\section{References}

[1] Cheah IG, Choo WY. A Review of Research on Child Abuse in Malaysia. Med J Malaysia 2010; 71(1): 86-98

[2] Lee LK, Chen PCY, Lee KK, Kaur J. Premarital sexual intercourse among adolescents in Malaysia: a cross-sectional Malaysian school survey. Singapore Med J 2006; 47(6):476-481.

[3] Brown J, Cohen P, Johnson JG, Salzinger S. A longitudinal analysis of risk factors for child maltreatment: findings of a 17-year prospective study of officially recorded and self-reported child abuse and neglect. Child Abuse Negl 1998; 22(11): 1065-1078.

[4] Johari MZ, Wee LH, Hasan Nudin HS, Ujang E, Mohd Roslan N, Omar B, Chinna K. High Risk Health Behavior among Malaysian Adolescents: A Comaprison Between Gender. Global Journal of Health Science. 2020; 12(11): 152-165

[5] Hull TH, Hasmi E, Widyantoro N. "Peer" educator initiatives for adolescent reproductive health projects in Indonesia. Reprod Health Matters 2004; 12(23): 29-39.

[6] Kumar R, Raizada A, Aggarwal AK, Kaur M. Adolescent behaviour regarding reproductive health. Indian J Pediatr 2000; 67(12): 877-882.

[7] Low WY. Adolescent health: what are the issues and are we doing enough?. Singapore Med J 2006; 47(6): 453-455.
[8] Islam MN, See KL, Ting LC, Khan J. Pattern of Sexual Offences Attended at Accident and Emergency Department of HUSM from Year 2000 to 2003: A Retrospective Study. Malays J Med Sci 2006; 13(1): 30-36.

[9] Ab Rahman A., Ab Rahman R., Ibrahim Ml, Salleh H, Ismail SB, Ali SH, Muda WM, Ishak M, Ahmad A. Knowledge of sexual and reproductive health among adolescents attending school in Kelantan, Malaysia. Southeast Asian J Trop Med Public Health 2011; 42(3): 717-725.

[10] Anwar M, Sulaiman SA, Ahmadi K, Khan TM. Awareness of school students on sexually transmitted infections (STIs) and their sexual behavior: a cross-sectional study conducted in Pulau Pinang, Malaysia. BMC Public Health 2010; $10: 47$.

[11] Burchard A, Laurence C, Stocks N. Female international students and sexual health - a qualitative study into knowledge, beliefs and attitudes. Aust Fam Physician 2011; 40(10): 817-820.

[12] Langille DB, Andreou P, Beazley RP, Delaney ME. Sexual health knowledge of students at a high school in Nova Scotia. Can J Public Health 1998; 89(2): 85-89

[13] Kassim MS, George R, Kassim K, Begum M, Cherian MP, Tajudin AK, Chandran V, Anan A, Reddy R, Singh J. Child abuse and neglect as seen in General Hospital, Kuala Lumpur--a two year study. Med J Malaysia 1989; 44(2): 111-121.

[14] Pereda N, Guilera G, Forns M, Gomez-Benito J. The prevalence of child sexual abuse in community and student samples: a metaanalysis. Clin Psychol Rev 2009; 29(4): 328338.

[15] Leland, NL, Barth RP. Gender differences in knowledge, intentions, and behaviors concerning pregnancy and sexually transmitted disease prevention among adolescents. J Adolesc Health 1992; 13(7): 589599.

[16] Hendrickx K, Lodewijckx E, Van Royen P, Denekens J. Sexual behaviour of second generation Moroccan immigrants balancing between traditional attitudes and safe sex. Patient Educ Couns 2002; 47(2): 89-94.

[17] McCree DH, Wingood GM, DiClemente R, Davies S, Harrington KF. Religiosity and risky sexual behavior in African-American 
adolescent females. J Adolesc Health 2003; 33(1): 2-8.

[18] Dunne MP, Edwards R, Lucke J, Donald M, Raphael B. Religiosity, sexual intercourse and condom use among university students. Aust J Public Health 1994; 18(3): 339-341.

[19] Ab Rahman A., Ab Rahman R, Ismail SB, Ibrahim MI, Ali SH, Salleh H, Muda WM. Factors associated with attitude toward premarital sexual activities among schoolgoing adolescents in Kelantan, Malaysia. AsiaPacific Journal of Public Health 2012; 20(10): 18.

[20] Roche KM, Ellen J, Astone NM. Effects of outof-school care on sex initiation among young adolescents in low-income central city neighborhoods. Arch Pediatr Adolesc Med 2005; 159(1): 68-73.

[21] Schouten $B C$, van den Putte $B$, Pasmans $M$, Meeuwesen $L$. Parent-adolescent communication about sexuality: the role of adolescents' beliefs, subjective norm and perceived behavioral control. Patient Educ Couns 2007; 66(1): 75-83.

[22] Boohene E, Tsodzai J, Hardee-Cleaveland K, Weir S, Janowitz B. Fertility and contraceptive use among young adults in Harare, Zimbabwe. Stud Fam Plann 1991;22(4):264-71.

[23] Jones RK, Biddlecom AE. Is the internet filling the sexual health information gap for teens? An exploratory study. J Health Commun 2011; 16(2): 112-123.

[24] Somers CL, Paulson SE. Students' perceptions of parent-adolescent closeness and communication about sexuality: relations with sexual knowledge, attitudes, and behaviors. J Adolesc 2000; 23(5): 629-644.

[25] Monasterio E, Hwang LY, Shafer MA. Adolescent sexual health. Curr Probl Pediatr Adolesc Health Care 2007; 37(8): 302-325.

[26] Khanam M, Perveen S, Mirza S. Reproductive and sexual health issues: knowledge, opinion and attitude of medical graduates from Karachi. J Pak Med Assoc 2011; 61(7): 648-652.

[27] Song A, Richters J, Crawford J, Kippax S. HIV and sexual health knowledge and sexual experience among Australian-born and overseas-born students in Sydney. J Adolesc Health 2005; 37(3): 243.

[28] DeJong J, Jawad R, Mortagy I, Shepard B. The sexual and reproductive health of young people in the Arab countries and Iran. Reprod Health Matters 2005; 13(25): 49-59.

[29] Ancheta R, Hynes C, Shrier LA. Reproductive health education and sexual risk among highrisk female adolescents and young adults. $J$ Pediatr Adolesc Gynecol 2005; 18(2): 105-111. 